\title{
A COVID-19 és a szív- és érrendszeri betegségek összefüggései
}

\author{
Szemelvények a 2020. márciusi közleményekböl
}

\section{Apor Astrid}

\author{
Semmelweis Egyetem, Városmajori Szív- és Érgyógyászati Klinika, Budapest \\ Levelezési cím: \\ Dr. Apor Astrid, e-mail: aporastrid@gmail.com
}

A globalizáció és a humánpopuláció mozgásának mértéktelen fokozódása kedvez a mikrobák terjedésének, és a globális járványok kialakulása folyamatos fenyegetéssé vált az elmúlt 2 évtizedben. Az elmúlt hónapban számos publikáció jelent meg a SARS-CoV-2 (CoV-2) koronavírus által okozott betegség (COVID-19) és a szív- és érrendszeri megbetegedések (kardiovaszkuláris betegség, CVB) kapcsolatáról vezető tudományos folyóiratokban (EHJ, JACC, JAMA, Nature, Lancet). Biztosan megállapítható, hogy ezek a betegek fogékonyabbak a vírusra, a betegség lefolyása súlyosabb, több pulmonalis szövődmény lép fel, a mortalitás magasabb. A meglévő szív- és érbetegségek romlanak, a korábban nem érintett betegeknél is akut kardiális szövődmények alakulhatnak ki. A COVID-19 kezelésében jelenleg empirikusan alkalmazott gyógyszereknek is lehetnek kardiális mellékhatásai. Felmerül a gyanú, hogy a korábbi koronavírus-járványokhoz (SARS, MERS) hasonlóan a fertőzöttekben hosszú távú kardiális, kardiometabolikus mellékhatások lesznek igazolhatóak. Jelenleg 80 klinikai tanulmány fut a betegség különböző aspektusainak és a terápiás lehetőségek felkutatására, valamint nagy betegszámú regiszterek adataiból próbálják meghatározni, hogy az ACEi/ ARB-szedő populációban eltérő-e a betegség előfordulási gyakorisága és lefolyása.

Kulcsszavak: SARS-CoV-2 koronavírus, cardiovascularis betegségek, fertőző betegségek, járvány

\section{Covid-19 and Cardiovascular Disease, overview of the publications from March 2020}

Globalization and the human population's excessive travel favours the spread of microbes; global epidemics have presented a continuous threat over the last two decades. Many of the leading clinical journals (EHJ, JACC, JAMA, Nature, Lancet) have recently published articles regarding the relation of cardiovascular diseases (CVD) and the COVID-19 pandemic caused by the SARS-CoV-2 coronavirus. Research suggests that patients with CVD are definitely more susceptible to the virus the clinical course is more severe, pulmonary complications appear with a higher frequency and the mortality rate is higher. Pre-existing cardiovascular diseases deteriorate and patients with no previous cardiovascular disease can also suffer from acute cardiac complications. In addition, pharmaceutical drugs used empirically in the treatment of COVID-19 might lead to cardiac side effects. There is a suspicion that similarly to previous coronavirus epidemics (SARS, MERS), infected patients might develop long-term cardiac and cardio-metabolic complications. There are currently 80 clinical studies exploring the different aspects of the disease and its possible treatment. Furthermore, it is under investigation whether the incidence and the clinical course of COVID-19 are different in patients taking ACEi/ ARB medication.

Keywords: SARS-CoV-2 coronavirus, cardiovascular diseases, infectious diseases, pandemia

Legfontosabb rövidítések

kardiovaszkuláris: CV, kardiovaszkuláris betegség: CVB, iszkémiás szívbetegség: ISZB, akut miokardiális infarktus: AMI, akut koronáriaszindróma: $\mathrm{ACS}$, perkután koronária-intervenció: $\mathrm{PCI}$, krónikus obstruktív tüdőbetegség: COPD

A kézirat 2020. 04. 07-én érkezett a szerkesztőségbe, 2020. 04. 10-én került elfogadásra. 


\section{Bevezetés}

A SARS-CoV-2 béta-corona RNS-vírus (1), tüske fehérjéjével a tüdőben és a szívben is megtalálható ACE2-receptorokhoz kötődik 10-20-szor nagyobb affinitással, mint a SARS-CoV (2). Átlagosan 2-7 nap inkubációs időt követően hozza létre a koronavírus-betegséget (coronavirus desease 2019, COVID-19). Az ACE2-enzim bontja az angiotenzin II-t, angiotenzin 1-7 jön létre (heptapeptid), ami potens vazodilátor. Az ACE2 müködése protektív számos kardiovaszkuláris (CV) betegségben, mivel a renin-angiotenzin-aldoszteron (RAAS) rendszer ellenregulátora: véd a hipertenzió, miokardiális fibrózis, hipertrófia, ateroszklerózis és aritmiák kialakulásával, valamint a só- és vízretencióval szemben $(3,4)$. A víruskötődés következtében az ACE2 protektív biokémiai útvonalai gátlódnak, a proinflammatorikus citokinek termelődése nő, a kialakuló SIRS (Systemic Inflammatory Response Syndrome) többszervi elégtelenséghez vezethet (5). A RAAS-gátlók nem hatnak az ACE2-receptorokra. A RAAS-gátlót szedőknél az ACE2-expresszió fokozott, a CoV-fertőzötteknél csökkent. Állatkísérletekben az ACE-inhibitorok protektívnek bizonyultak a SARS-CoV-2 okozta súlyos pulmonalis szövődményekkel szemben (6), de humán adat még nincsen. A gyógyszeres RAAS-gátlás és a COVID-19 összefüggése (előnyös-e, vagy káros) jelenleg spekulatív (7), az ezt kutató, folyamatban lévő tanulmány a „Losartan for Patients With COVID-19 Requiring Hospitalization" (https://clinicaltrials.gov/ ct2/show/NCT04312009). Kardiovaszkuláris betegségekben továbbra is az ajánlások által előírt gyógyszeres terápia optimalizálása javasolt, csökkentendő a CoV-2-fertőzés súlyosságát.

A CV-betegség fokozott fogékonyságot jelent CoV-2-infekcióra, a diagnózis felállítása pedig nehezített.

A hipertóniában (HT), diabéteszben (DM), koszorúér-betegségben (ISZB) és cerebrovaszkuláris betegségben szenvedők könnyebben megfertőződnek. A CoV-2-vel hospitalizált betegek 40\%-ának van kardiovaszkuláris vagy cerebrovaszkuláris betegsége. Az első nagyobb esetszámú kínai publikációban a leggyakoribb komorbiditások sorrendje: HT, DM, ISZB, cerebrovaszkuláris betegségek, pangásos szívelégtelenség, krónikus veseelégtelenség, COPD, tumoros betegségek (8). A Kínai Nemzeti Egészségügyi Bizottság (NHC) adatai szerint a CoV-2-fertőzöttek 35\%-ának volt hipertóniája, és 17\%-ának ISZB-je (7). A fokozott fogékonyság oka lehet a szív- és érrendszeri betegek magasabb ACE2-szekréciója/expressziója (2).

\section{CVB esetén a COVID-19 lefolyása súlyosabb, mortalitása magasabb}

A COVID-19 mortalitása a legnagyobb a szív- és érrendszeri betegek között (13,2\%) más kísérőbetegségekkel
Összehasonlítva is aránytalanul magas, 8-9-szeres diabétesz $(9,8 \%)$ és hipertónia $(8,4 \%)$ esetén, míg ezen betegségek hiányában $1 \%$ körül mozog $(9,10)$. A súlyosabb lefutást mutató, intenzív osztályon kezeltek között is magasabb a hipertóniások, a szív- és érrendszeri, valamint a cerebrovaszkuláris betegségben szenvedők aránya (11). A súlyosabb lefolyás, magasabb mortalitás hátterében húzódó patomechanizmusok: fokozott ACE2-expresszió + excesszív citokinfelszabadulás + hypoxaemia (2). A tumoros kísérőbetegségek tekintetében a tüdőtumoroknál és az aktív tumorellenes kezelés esetén a legrosszabb a prognózis (12).

CVB esetén a COVID-19 súlyosabb lefolyásának és magasabb mortalitásának kóroki összetevői a következők (7): - A CVB és a COVID-19 kölcsönösen nehezítik egymás diagnosztikáját, késleltetve a terápiát.

- CV-betegeknél a CoV-2 pulmonalis szövődményei súlyosabbak.

- A CoV-2-infekció a meglévő CVB romlásához, destabilizációjához vezet.

- A CoV-2-nek akut kardiális szövődményei lehetnek a CV-betegséggel rendelkezőkben és nem rendelkezőkben egyaránt.

- Akut kardiális szövődmény kialakulása esetén gyakrabban lép fel ARDS, veseelégtelenség, koagulációs zavar, rosszabb a prognózis.

- A COVID-19 kezelésére használt gyógyszereknek lehetnek kardiális mellékhatásai.

\section{CVB és COVID-19: kölcsöno̊sen nehezített diagnosztika}

A szív- és érrendszeri betegségek és a COVID-19 klinikai tünetei jelentős átfedésben vannak (dyspnoe, fáradékonyság, palpitáció, mellkasi diszkomfort), ezért a koronavírus-fertőzés gyanújának felvetése és a diagnózis felállítása késlekedhet, illetve nehezített CV-betegeknél (4). A már zajló COVID-19 esetén pedig az akut miokardiális infarktus (AMI) klasszikus megjelenése és tünetei homályosulhatnak el, szintén késleltetve a diagnózist és az invazív oki terápiát (13)!

CV-kíséröbetegség esetén a COVID-19 pulmonalis szövődményei súlyosabbak.

A CoV-2-infekció a meglévő CVB romlásához, destabilizációjához vezet, és a CoV-2-nek akut kardiális szövődményei lehetnek a CV-betegséggel rendelkezőkben és nem rendelkezőkben egyaránt.

A CoV-2-fertőzés precipitálja a kardiális státusz romlását, destabilizálva számos szívbetegséget, pl. a krónikus szívelégtelenséget vagy a koszorúér-betegséget. Ennek hátterében számos faktor áll. A 3 fő patomechanizmus (5):

- Relatív iszkémia okozta károsodás.

- Vírusmediált direkt károsodás.

- Szisztémás gyulladásmediált károsodás (citokinek + SIRS). 
A szív- és érrendszeri betegségben szenvedők kardiális rezervje eleve beszűkült. Az infekció fokozza a szövetek, szervek metabolikus és perfúziós igényét, a tüdőkárosodás viszont hypoxaemiához vezet relatív iszkémiát hozva létre $\left(\mathrm{O}_{2}\right.$ demand/supply inbalance, type-II myocardium-károsodás). A vírusmediált direkt károsodásról kevés adatunk van egyelőre. A kiegyensúlyozatlan $\mathrm{T}_{1^{-}}, \mathrm{T}_{2}$-helper-sejtaktivitás fokozott citokin-kiáramláshoz, citokinviharhoz vezet, ami myocardiumkárosító (2). A korábbi szív- és érrendszeri betegségektől mentes COVID-19-áldozatok 12\%-ában is kimutatható volt a szívizom-károsodás (7). Azoknál a betegeknél, akiknél kardiális érintettség is kialakul, magasabb a C-reaktív protein-, az NT-proBNP- és a kreatininszint, súlyosabb a radiomorfológiai és klinikai kép, gyakrabban van szükség lélegeztetésre, gyakoribbak az alvadási rendellenességek, és igen rossz a prognózis (8).

\section{A CoV-2-infekció leggyakoribb kardiális szővődményei}

Az eddigi kínai közlemények a betegek 20-25\%-ában számolnak be kardiális érintettségről: akut szívelégtelenség, aritmiák, pitvarfibrilláció, AMI, myocarditis, cardiac arrest formájában. A közölt leggyakoribb kardiális panaszok/tünetek: mellkasi szorítás, palpitáció, hipotenzió, tachycardia/bradycardia, hirtelen szívhalál (2).

\section{Szívelégtelenség}

Az akut szívelégtelenség előfordulási gyakorisága a túlélők körében 23\%, de jóval magasabb az elhalálozók között (52\%). Hátterében aritmia, akut koronáriaszindróma (ACS), fulmináns myocarditis, stressz indukálta cardiomyopathia állhat (14).

\section{Aritmiák}

Az egyik első retrospektív kínai publikáció beszámolt már arról, hogy a betegek 17\%-ában fordul elő ritmuszavar, de ez az arány még magasabb az intenzív osztályon kezelteknél (44\%) (11). A hypoxaemia pitvarfibrillációt indukálhat. Az influenzajárványok alatt gyakoribbak az ICD-sokkok, erre számíthatunk a COVID-19 során is. Az aritmiák kezelése nem tér el a szokványostól, de a szisztémás gyulladás prokoaguláns hatása miatt nehezített, és kisebb effektivitású lehet az antitrombotikus terápia (4).

\section{ISZB, AM |}

A koszorúérbetegeknél a vírus indukálta szisztémás gyulladás plakkrupturához, ACS-hez vezethet. A COVID-19 és az ACS együttes előfordulásakor igen rossz a prognózis. A korábban $\mathrm{PCl}-\mathrm{n}$ átesetteknél a gyulladás prokoaguláns hatása miatt a stenttrombózis veszélye megnő, indokolt az intenzifikált trombocitaaggregáció-gátlás és a trombocitafunkció monitorizálása (5). A statinok gyulladáscsökkentő, plakkstabilizáló hatásuk miatt különös jelentőséggel bírnak az infekció idején.

\section{Myocarditis}

A 2016-os MERS-CoV-vírus által okozott járványban myocarditis és szívelégtelenség kialakulását is megfigyelték (7). A COVID-19-pandémiában még nincs sok adat, de anekdotikus közlések már vannak egyszerü és fulmináns lefolyású myocarditis eseteiről $(15,16)$. CoV-2-fertőzöttek szívizomzatában mononukleáris infiltrátumok mutathatók ki. A vírusinvázióra adott túlzott immunválasz során felszabaduló citokinek (TNF, II-6 család) negatív inotróp hatása ismert, és feltételezhető a vírus direkt károsító hatása is, jóllehet a szívizomzatból eddig nem lett kimutatva a vírus RNS-e $(8,15)$. Myocarditis gyanúját vessék fel a szívritmuszavarral, kardiális biomarker-emelkedéssel, EKG-elváltozásokkal járó kardiális panaszok akár akut szívelégtelenséggel vagy anélkül is (17). Ilyen esetekben az echokardiográfiát követően PET-CT vagy CMR is végezhető.

\section{Kardiogén sokk}

A súlyos állapotú CoV-2-fertőzötteknél típusosan kevert, kardiogén és vazodilatatív sokk alakul ki, ezért pulmonalis artériás katéter bevezetése válhat szükségessé a terápia vezetéséhez (17). Az eddigi legnagyobb kínai beszámolóban az összes fertőzött 1,1\%-a lett sokkos (18). Az ún. „citokinvihar” diszfunkcionális, kontrollálatlan szisztémás gyulladásos reakció a limfociták és makrofágok folyamatos aktivációjával és proliferációjával, amely methemoglobinaemiával, hemodinamikai instabilitással, az alvadási rendszer aktiválódásával és többszervi elégtelenséggel jár. A citokinek a szívizomsejtek apoptózisát, nekrózisát idézik elő, súlyosan károsítva a kardiális funkciót (8).

Érdekes a COVID-19 időbeli lefolyásáról szóló egyik kínai kórházi beszámoló (11): az első tüneteket követően a nehézlégzés leggyakrabban az 5. napon lépett fel, kórházi felvételre a 7. napon került sor, az ARDS a 8. nap körül alakult ki, és a túlélők/nem túlélők laborparaméterei a 9-11. napon váltak szét. Az ARDS gyakorisága $19,6 \%$ volt, a betegek $8,6 \%$-a sokkos volt. Az intenzív osztályon lévők 47\%-át kellett lélegeztetni, $36 \%$ kapott vazopresszort, 5\% vesepótló kezelést, 11\% ECMO-t. Az intenzív osztályra kerülők aránya az eddig legnagyobb esetszámú kínai tanulmányban $5 \%$ volt, gépi lélegeztetésre a betegek 6,1\%-a szorult, a halálozás $1,3 \%$-os volt (18).

\section{Kit és hogyan monitorizáljunk kardiális szővő̃dmény irányában?}

A troponinemelkedés (hs-cTnl), új keletű aritmia és akut szívelégtelenség tünetei mindig keltsék fel a kardiális szövődmény gyanúját. Troponinemelkedés 17\%-ban detektálható, és szignifikánsan magasabb a nem túl- 
élőkben és az intenzív osztályon kezeltekben. A troponin- és BNP-mérés hospitalizációkor majd a mérés ismétlése segít azonosítani azt a betegalcsoportot, amelyben kardiális szövődmény valószínűsíthető, és rossz prognózisú (lásd What Does Elevated Troponin Mean in COVID-19? https://www.medpagetoday.com/ infectiousdisease/covid19/85605). Monitorizáljuk azon betegek troponinszintjét, akiknek szív- és érrendszeri betegségük van, antineoplasztikus kezelésben részesülnek, kardiális szövődmény gyanúja merül fel a klinikai tünetek alapján, vagy állapotjavulást nem mutatnak (2).

\section{Telemetria}

Kísérő CVB, kardiális biomarker-emelkedés, új keletű aritmia vagy súlyosabb lefolyású betegség esetén indokolt.

\section{Echokardiográfia}

Rutinszerűen nem indokolt, csak azokban az esetekben, ha a kezelést befolyásolja az eredménye. Megfontolandó CV-megbetegedés vagy rizikófaktorok jelenlétekor, indokolt szívelégtelenség-tünetek, aritmia, EKG-változás, cardiomegalia megjelenésekor (13). Az intenzív osztályon pedig az instabil betegeknél, jobbszívfél-elégtelenség, pulmonalis hipertónia gyanújakor. A képalkotó stratégiát a friss EACVI-ajánlás tartalmazza (19).

\section{Akut kardiális szövődmény kialakulása esetén gyakrabban lép fel ARDS, veseelégtelenség, koagulációs zavar}

Egy 416 beteget vizsgáló kínai tanulmányban (8) az akut kardiális érintettséget mutatók között 5-szörös volt az invazív lélegeztetés szükségessége $(22 \% \leftrightarrow 4,2 \%)$, 3,9-szeres az ARDS előfordulása (59\%↔15\%), 28-szoros az akut vesekárosodás $(8,5 \% \leftrightarrow 0,3 \%)$ és 4 -szeres a koagulációs zavar $(7,3 \% \leftrightarrow 1,8 \%)$ a kardiális károsodást nem mutatókhoz viszonyítva.

\section{A COVID-19 kezelésére használt gyógysze- reknek lehetnek kardiális mellékhatásai}

Az eddigi publikációkban alkalmazott antivirális szerek: lopinavir, ritonavir (nem hatékonyak), oseltamivir, remedesivir, favipiravir (hatékonyságukról nincs adat). Számos antivirális szer aritmiát, szívelégtelenséget okoz önmagában is (7). A hydroxychloroquine (telítő dózis első nap: 2×400mg, fenntartó dózis 2×200mg 4 napig) antivirális hatása igazolt: növeli a sejt-PH-t, ezzel akadályozza a vírus celluláris kötődését és fúzióját (17). A rövid távú alkalmazásnak nem ismertek kardiális mellékhatásai, a hosszú távú kezelés QT- és PR-prolongációt, blokkot, aritmiát, cardiomyopathiát okozhat.
Kipróbálás alatt lévő szerek az IL-6-blokkolók: tocilizumab, sarilumab. Sok helyen a hipotetikusan hatékony kortikoszteroidokat is bevetik a citokinvihar gátlására, és anekdotális közlések vannak plazmaferezis és extrakorporális citokinabszorberek (CytoSorbents) alkalmazására is. Az antiaritmiás amiodaronról kimutatták, hogy invitro gátolja a SARS-CoV terjedését, ennek klinikai jelentősége még nem ismert (20).

\section{ECMO}

A WHO útmutatója refrakter ARDS esetén ECMO-beültetést javasol a szokványos indikációs kritériumok alapján, az implantőr fokozott védelmére figyelve (21). Az ECMO hasznát COVID-19-ben az ELSOCard regiszter vizsgálja.

\section{A COVID-19 feltételezett krónikus kardiovaszkuláris szővődiményei}

A közösségben szerzett pneumónián átesett betegeknél még az indexeseményt követően sokáig megmarad a szisztémás inflammatorikus és prokoaguláns aktivitás, és a szív- és érrendszeri megbetegedések fokozott kockázata akár 10 évig is fennállhat. Feltételezhetjük, hogy ez igaz CoV-2-pneumónia esetén is. Az alkalmazott kortikoszteroid-kezelés szintén hosszú távon növeli a CV-események fellépésének kockázatát (5). A 2002es SARS-pandémia túlélöinek $68 \%$-ában maradt viszsza hosszú távon lipidanyagcsere-zavar és $60 \%$-ában glükózanyagcsere-zavar. A kóroki vírusok hasonlósága miatt ennek veszélye fennáll a COVID-19 lezajlását követően is (22).

\section{Általános megfontolások szív- és érrend- szeri betegeknél a COVID-19-pandémiában}

Az optimális gyógyszeres terápia beállítása a nemzetközi ajánlásoknak megfelelően különösen fontos a járvány idején. $A \mathrm{CV}$-betegségben szenvedők fokozottan fogékonyak nemcsak a CoV-2-re, hanem a szekunder bakteriális felülfertőződésre is, ezért feltétlenül legyenek beoltva a pneumococcus- (és influenza-) védőoltásokkal (13)! A járvány alatt a krónikus szívbetegek számára kiépítendő a telefonos vagy internetes telekonzultációs lehetőség („cloud clinic”), mivel nem tanácsos személyesen megjelenniük az ambulanciákon, csak ha nagyon szükséges.

\section{Nyillatkozat}

A szerző kijelenti, hogy az összefoglaló közlemény megírásával kapcsolatban nem áll fenn vele szemben pénzügyi vagy egyéb lényeges összeütközés, összeférhetetlenségi ok, amelyek befolyásolhatják a közleményben bemutatott eredményeket, az abból levont következtetéseket vagy azok értelmezését. 


\section{Irodalom}

1. Lu R, Zhao X, Li J, et al. Genomic characterisation and epidemiology of 2019 novel coronavirus: implications for virus origins and receptor binding. Lancet 2020; 395: 565-74.

2. Sarju Ganatra, Sarah P, Hammond and Anju Nohria. The Novel Coronavirus Disease (COVID-19) Threat for Patients with Cardiovascular Disease and Cancer. JACC CardioOncology March 2020 doi: 10.1016/j.jaccao.2020.03.001

3. Gurwitz D. Angiotensin receptor blockers as tentative SARSCoV-2 therapeutics. Drug Dev Res 2020 Mar 4. doi: 10.1002/ ddr.21656. (Epub ahead of print)

4. Chengzhi Yang, Zening Jin. An Acute Respiratory Infection Runs Into the Most Common Noncommunicable Epidemic-COVID-19 and Cardiovascular Diseases. JAMA Cardiol Published online March 25, 2020. doi:10.1001/jamacardio.2020.0934

5. Tian-Yuan Xiong, Simon Redwood, Bernard Prendergast, Mao Chen. Coronaviruses and the cardiovascular system: acute and long-term implications. European Heart Journal, ehaa231, https:// doi.org/10.1093/eurheartj/ehaa231

6. de Simone G. Position statement of the ESC Council on Hypertension on ACE-inhibitors and angiotensin receptor blockers. March 13, 2020. https://www.escardio.org/Councils/Council-on-Hypertension(CHT)/News/position-statement-of-the-esc-council-on-hypertension-on-ace-inhibitors-and-ang (accessed March 23, 2020).

7. Zheng Y, Ma Y, Zhang J, et al. COVID-19 and the cardiovascular system. Nat Rev Cardiol 2020. https://doi.org/10.1038/s41569-0200360-5

8. Shaobo Shi, Mu Qin, Bo Shen, Yuli Cai, et al. Association of Cardiac Injury With Mortality in Hospitalized Patients With COVID-19 in Wuhan, China. JAMA Cardiol Published online March 25, 2020. doi:10.1001/jamacardio.2020.0950

9. Report of the WHO-China Joint Mission on Coronavirus Disease 2019 (COVID-19). 16-24 February 2020. Available at: https://wwwwhoint/docs/defaultsource/coronaviruse/who-china-joint-missionon-covid-19-final-reportpdf; Accessed March 9, 2020.

10. Chen N, Zhou M, Dong X, et al. Epidemiological and clinical characteristics of 99 cases of 2019 novel coronavirus pneumonia in Wuhan, China: a descriptive study. Lancet 2020; 395: 507-513.

11. Dawei Wang, Bo Hu, Chang Hu, Fangfang Zhu, Xing Liu, et al. Clinical Characteristics of 138 Hospitalized Patients With 2019 Novel Coronavirus-Infected Pneumonia in Wuhan, China JAMA 2020; 323(11): 1061-1069. doi:10.1001/jama.2020.1585
12. Liang W, Guan W, Chen R, et al. Cancer patients in SARSCoV-2 infection: a nationwide analysis in China. Lancet Oncol 2020; 21: 335-337.

13. American College of Cardiology. ACC clinical bulletin: COVID-19 clinical guidance for the cardiovascular care team. Reviewed March 6, 2020 https://www.acc.org/ /media/665AFA1E710B4B3293138D1 4BE8D1213.pdf.

14. Zhou F, Yu T, Du R, et al. Clinical course and risk factors for mortality of adult inpatients with COVID-19 in Wuhan, China: a retrospective cohort study. Lancet 2020. https://doi.org/10.1016/ S01406736(20)30566-3; PMID: 32171076; (Epub ahead of press.)

15. Inciardi RM, Lupi L, Zaccone G, Italia L, Raffo M, Tomasoni D, Cani DS, et al. Cardiac Involvement in a Patient With Coronavirus Disease 2019 (COVID-19) JAMA Cardiol 2020 Mar 27. doi: 10.1001/ jamacardio.2020.1096. (Epub ahead of print)

16. $\mathrm{Hu} \mathrm{H}$, Ma F, Wei $\mathrm{X}$, Fang $\mathrm{Y}$. Coronavirus fulminant myocarditis saved with glucocorticoid and human immunoglobulin. Eur Heart $\mathrm{J}$ 2020. https://doi.org/10.1093/eurheartj/ehaa190; PMID: 32176300; (Epub ahead of press.)

17. Aniket S, Rali C, Andrew J. Sauer A. COVID-19 Pandemic and Cardiovascular Disease. US Cardiology Review 2020; 14: e01.

18. Wei-jie Guan, Zheng-yi Ni, Yu Hu, Wen-hua Liang, Chun-quan Ou, et al. for the China Medical Treatment Expert Group for COVID-19. Clinical Characteristics of Coronavirus Disease 2019 in China. February 28, 2020 DOI: 10.1056/NEJMoa2002032

19. Skulstad H, Cosyns B, Popescu BA, Galderisi M, Salvo GD, et al. COVID-19 pandemic and cardiac imaging: EACVI recommendations on precautions, indications, prioritization, and protection for patients and healthcare personnel. European Heart Journal - Cardiovascular Imaging, jeaa072, https://doi.org/10.1093/ehjci/jeaa072

20. Stadler $\mathrm{K}, \mathrm{Ha} \mathrm{HR}$, Ciminale V, et al. Amiodarone alters late endosomes and inhibits SARS coronavirus infection at a post-endosomal level. Am J Respir Cell Mol Biol 2008; 39: 142-9. https:// doi. org/10.1165/rcmb.2007-02170C; PMID: 18314540.

21. WHO. Clinical management of severe acute respiratory infection when novel coronavirus (2019-nCoV) infection is suspected: interim guidance. March 13, 2020.

https://www.who.int/publications-detail/clinical-management-ofsevere-acute-respiratory-infection-when-novel-coronavirus-(ncov)infection-is-suspected (accessed March 23, 2020).

22. Wu Q. et al Altered lipid metabolism in recovered SARS patients twelve years after infection. Sci Rep 2017; 7: 9110. 